\title{
Educating for Enterprise
}

Feature Interview 3.1. Jordan Gower, Ceramicist, Emerging Maker (Interviewed January 2016)

Jordan: '[It was a] TAFE [ ... ] when I went through the degree and I know it's changed a little now with the merger with Flinders [University] and that sort of thing. When I went through it was a very hands-on, very sort of technical, practical-it was basically a tech college where you learnt some skills and you do some thinking and it wasn't necessarily the research-focused sort of ethos that we have here. When I came over to uni, certainly the skills that I learnt there were very beneficial, but the main focus of [the] course was on thinking and research and being able to apply or maybe being able to understand your own ways of making through an academic structure, which is fantastic. For me [though], if I hadn't have done that degree I wouldn't be where I am now, and I wouldn't think about the materials and the objects and the practical sort of side of things as clearly as I do if I hadn't done it. The sort of references and the influences that $[\ldots]$ who were the coordinators gave-I mean they have such a breadth of knowledge that you just wouldn't be able to

(continued)

(C) The Author(s) 2020

S. Luckman, J. Andrew, Craftspeople and Designer Makers in the

Contemporary Creative Economy, Creative Working Lives, https://doi.org/10.1007/978-3-030-44979-7_3 


\section{(continued)}

find all these things if you sort of tried on your own, and again it's that network between that sort of cohort that really clarified what you were doing, and you had sort of clarify it otherwise you would sort of fall back and you had to write about it but it was incredibly important and I find writing is sort of as fascinating as making; it's sort of the ways you can structure certain things and how sort of ephemeral writing is yet how potent it is at the same time. [ ... ] I can't really say what the sort of undergrad program at uni is like, but from what I can see it's certainly not as hands-on [as the earlier TAFE program] and the sort of technical skills maybe quite aren't there unless people have had prior experience or [are] just amazingly naturally talented or really focused. I think the technical level it's a little lopsided compared to TAFE but of course that is changing [ $\ldots$ ] but I think it [being] a little bit more balanced in both schools would be better. They're integrated-you can't make things and not think.'

Interviewer: 'Especially when you need to tell the story of them and why you make them in this day and age to communicate?'

Jordan: 'Exactly and you can sort of make things having not gone through a degree and of course you can be successful in a retail and a commercial sense, and of course you can still speak about it, but I don't think it has the layers of meaning compared to say going through a visual arts degree or even just having that historical context and social context and all these different contexts that exist. Whether you like it or not you have to understand what's happening which I find a lot of the same sort of objects are being made and people are really enjoying those objects, but at the same time the makers and perhaps the people that are buying them don't understand that.' (Fig. 3.1) 


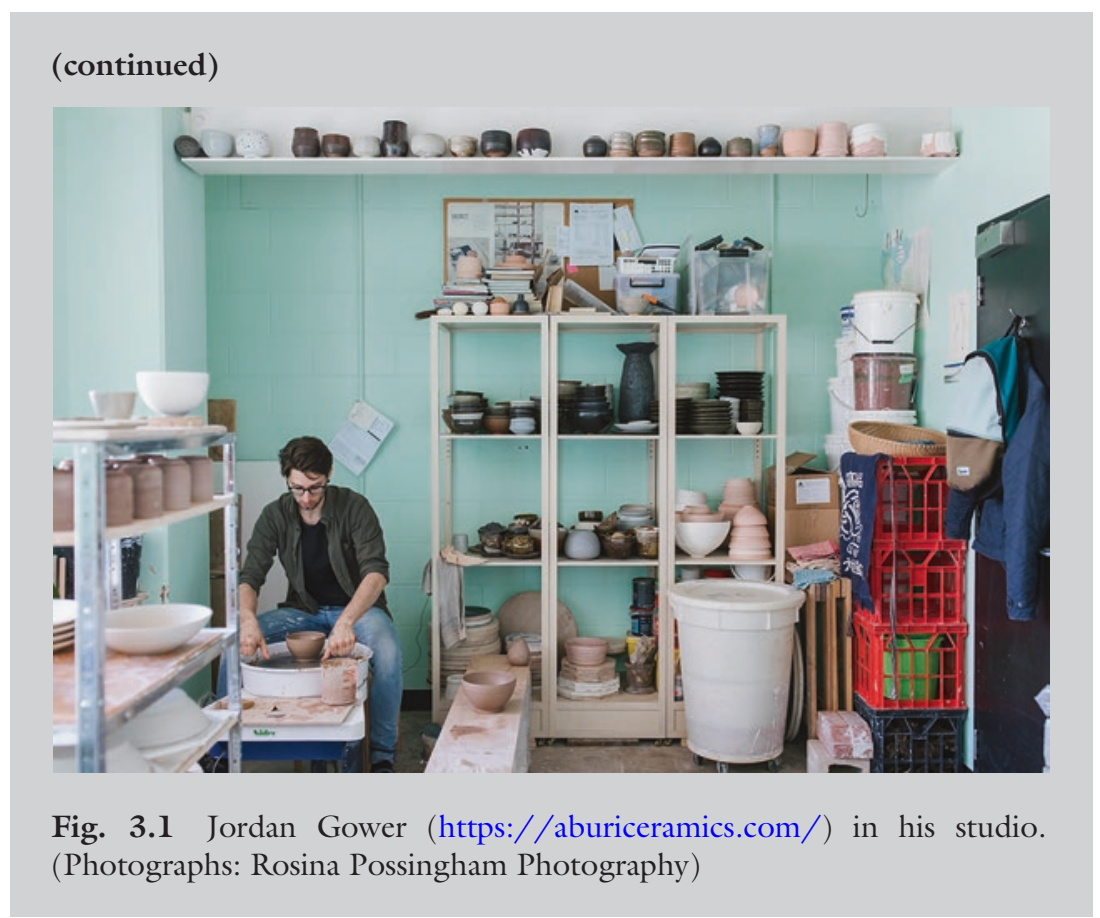

The account that opens this chapter points to many of the ongoing debates in Australian craft and design education, in particular lingering tensions between where that education should reside (vocational versus university education) and thus of what the balance should be in terms of practical technical skills versus creative thinking. These continue to be debated in Australia and elsewhere (Banks and Oakley 2016). In order to discuss this project's findings, therefore, it is important to locate contemporary Australian craft and designer maker practice within the larger, shifting picture of arts education and training in Australia and even beyond. Many of the funding challenges facing Australian higher education providers, such as the loss of studio space and tutor funding, are not unique to this national context and are being felt across much of the Global North. This chapter will provide a necessarily brief historical overview of the models of training available to support skills development for the applied arts in Australia, from colonial cottage industries to the educational 
experiences of the contemporary craftspeople and designer makers who participated in this study. In doing so, it will highlight significant contemporary Australian federal and state government political and economic policy agendas that have directly and indirectly influenced changes to the nature, form and institutional investment in education supporting the development of contemporary Australian makers. The second half of this chapter reports on the research participants' educational experiences and sense of how well prepared they were upon graduating to establish and sustain a viable creative enterprise. Despite the prospect of low levels of income earned from their creative practice, people continue to be attracted to the possibility of carving a creative career by pursuing their crafts or designer maker interests. Furthermore, although the availability of online information about making techniques, materials and equipment suppliers, micro-entrepreneurial business skills and accessing markets has opened up the field further to self-starter or DIY makers, the majority of the makers we spoke to in this project continue to pursue some form of post-secondary qualifications and/or training to enable their practice. $^{1}$

\section{Craft in Colonial Australia}

Any account of pathways into creative work in Australia must acknowledge the Euro-centric focus of higher education. Most courses fail to acknowledge that making practice and creative enterprise in Australia stems back tens of thousands of years. For millennia, Aboriginal and Torres Strait Islander Australians have been making objects of utility and crafting expressions of spirituality, in the process passing on essential knowledge about techniques and the places where raw materials can be sourced. Having brought these skills and others into contemporary making practices, generally without formal tertiary educational frameworks and institutions, Aboriginal and Torres Strait communities have expanded the outreach of more than 50 regional social enterprise art centres, so that they now include an extended network of small group and individual makers producing globally unique craft works across a spectrum of creative practice and price points (discussed further in Chap. 6). Mostly, these centres are run by Anglo-European artists/arts managers with an arts education from a technical college or university, which the majority of Aboriginal and Torres Strait Islanders making the creative works are unlikely to experience. With this important and notable exception, the Australian contemporary craft and designer maker economy is dominated 
by people from Anglo-European backgrounds. It is in this context that we now consider the influence of the various modes of skills acquisition, education and training (influenced by the social, class, economic and political agendas of the day) that have supported the development of craft-based enterprises in Australia, from its early colonial industry to the contemporary designer maker of the early twenty-first century.

In January 1788 the 'First Fleet' arrived in Botany Bay, Sydney, from Britain to begin the process of creating the fledgling European Australian colony. As has been widely researched, this marked the beginning of colonisation, with its ongoing subsequent boat arrivals delivering their cargoes of convicts and settlers to the penal colonies of Van Diemen's Land (Tasmania), New South Wales and Western Australia. Between 1788 and 1868, the majority of the 165,000 British and Irish convicts transported to Australia were poor and illiterate, victims of the harsh social conditions and laws in the rapidly industrialising Georgian England. Apart from unskilled convicts, who worked mostly in labour gangs, each transportation to the colony also included semi-skilled convicts such as miners, craftsmen and tradesmen, who could be put to work to manufacture goods for the growing colonies. Irrespective of their place of origin and tenure of incarceration, all these people brought with them memories of the objects and making practices of their former lives, many of which they adapted and applied in the technically immature worksites of the forming colony. As with similar histories of European colonisation, Australia's Indigenous peoples were not perceived and respected as skilled knowers of the land and how to work with it. Rather, as British settlers went about the genocidal project of occupying a land deemed by the British authorities to be terra nullius - 'empty' or 'nobody's land'-the expertise of the Indigenous peoples was ignored and their presence viewed simply as a hindrance.

The settler economy reproduced many of the class divisions of its original societies, with the associated valorisation, or devaluing, of different workers and their skills. Industrial stations were established to support and supply food and everyday items to the work gangs and the camps transforming the Australian landscape from bushland to farmland, as well as the growing urban community. Convict labour was put to work to produce items such as footwear and clothing made from hides and wool from government farms and tools, and fittings forged with coal from the mines. The convicts working in these enterprises were commonly selected based on their employment and skills prior to being transported. The 
production of these goods resembled a 'factory line' approach, which increased efficiency. An example of this development of semi-skilled craft labour can be found in historical records of a Tasmanian penal settlement, where incarcerated boys were put to work making shoes, goods from timber and stone building products for use in the wider colony (Tuffin 2013, 6-10).

Then, as is still the case, Australia based its economy predominantly on trading its untransformed resources, such as wool, grain and ore. In the early decades of the colony, they were chiefly sent back to Britain. This export from Australia was balanced by British imports of consumer goods such as clothing, textiles, boots and shoes, food, drink and tobacco (Butlin $2013,3-8)$. Such imports tended to be more highly valued than locally produced goods, with a further hierarchy of values linked to place of origin: British and European goods were more highly rated than those from China. Rowan Ward (2002) illustrates the types of goods imported in his report of the excavation of ceramic objects from a property established in the late 1700s, occupying 109-113 George Street, Parramatta, in western Sydney. The dig found:

[a] wide range of decorative styles, in every conceivable shape, and with price ranges to suit all budgets [ ... ] meant that the imported United Kingdom ceramics so effectively dominated the field that locally produced ceramics, such as the early lead-glazed wares and imported ceramics from China, were not able to maintain their competitiveness within the market of mass production and ease of accessibility to goods. [ ... ] During the earlier years of colonial settlement the finer imported wares from both China and the United Kingdom were mainly purchased as tableware and teaware items, with the simple locally made wares ideally suited for uses mainly concerned with utilitarian roles (food preparation and storage, possible dairying, and toiletry). (Ward 2002, 68)

It was not until the great investment boom of the late 1870 s, following the Australian gold rushes of the mid-nineteenth century, that local industrial production began to diversify and grow.

This historical record of the impact of imported crafted consumer goods signals a contributing factor to Australia's limited industrial production of many of the goods that required artisanal skill and labour, and by corollary, limited cultural appreciation for, and economic and industrial investment or training for the production of refined utilitarian objects or objets d'art. Beyond the making legacies that individual migrants brought 
with them from their countries of birth, non-Aboriginal making in Australia has a very short history. This historical narrative repeated itself in the late 1980s after the alternative lifestyle and artisanal boom period of the 1960s and 1970s had died down. Craftspeople and designer makers who had once been able to generate a good income from their making practice found it increasingly hard to compete with overseas manufacturers who began copying the decorative styles of the handmade limited production objects. This was particularly challenging for ceramists/potters, furniture makers and jewellers.

\section{Formalising Applied Arts Education: Mechanics Institutes in Australia}

Since the establishment of the colony, support in Australia for the acquisition of craft and making skills and for education in the applied arts has run in step with the modes of production, training and education in the UK. Perhaps the most tangible example of this was the strong presence across the country of mechanics institutes, which were the key forerunner of public libraries and adult education in Australia. Their origin is attributed to Glaswegian Dr George Birkbeck, who in 1799 advocated the need to educate the 'working man'. His series of free lectures led to the establishment of the Edinburgh School of Arts (1821) and the London Mechanics' Institute (1823). The institutes were intended not only to facilitate the dissemination of knowledge but also to provide a 'civilising' (and sobering) influence on the working classes. The growth of the mechanics institute movement coincided with the Industrial Revolution. When machinery began to dominate production processes and modes of labour, the artisanal labourer moved from being an artisanal cottage producer to being a 'mechanic' working the machines of production.

Mechanics institutes therefore spread from Britain to its colonies and lectures were offered free of charge in the evenings to incentivise and enable workers to attend them. In Australia, the institute building was often one of the first public buildings in a town and served many purposes (e.g. schoolhouses, banks, health centres and polling booths) while communities were being built (Prahran Mechanics' Institute n.d.). Sometimes derogatorily called poor man's universities or workingman's colleges, the mechanics institutes were essentially the first adult education schools in Australia (Baragwanath 2011). It is likely that this early, overt articulation 
of class distinction between universities and 'other' institutions of adult education is the origin of the persistent differentiation in respect and value accorded to academically focused education as opposed to trades or vocational education (as exemplified by the technical and further education or TAFE sector in Australia).

The first institutes or schools of arts (or 'athenaeums') were established in Sydney in 1833, Newcastle in 1835, Melbourne and Adelaide in 1839, Launceston in 1842 and Brisbane in 1849 (Baragwanath 2011). The focuses of the institutes varied across the individual colonies and were closely related to the demographic, economic, geographic and environmental resources of the communities. Institutional names reflected the industrial and economic focus of the region; for example, 'Schools of Mines' and 'Agricultural Colleges' generally were found in rural communities, whereas 'Working Men's Colleges', 'Mechanics Institutes' and 'Schools of Mines and Industries' were usually established within cities and urban areas.

The status attached to particular skills and forms of making in the colonial Australian context had a complicated influence on the development of the institutes. As noted, the intention in establishing these sites of knowledge and skills sharing was not just to disseminate technical know-how among the developing local economies. The social promise of the school of arts movement held enormous appeal in colonial society:

The transfer of the concept [of mechanics institutes] to the Australian colonies created an intriguing scenario, for initially there was no industrialised society here. Rather, there was great demand for skilled labour for building purposes, and a very unequal society of convicts, emancipists and free immigrants. The concept of acquiring skills for the labourers was attractive enough, but the possibility that the movement could help stabilise society was irresistible. (Beddoe 2003, 123)

For a young, emerging nation built on a population of (ex-)convicts, (gold) diggers and those who felt their chances in the colonies could not be any worse than their standing in British or European society, the Victorian, middle-class impetus behind the institute movement, with its reformist, 'civilising' character, had a particularly strong currency.

Even though the ambitions for the institute movement to support Australia's industrial development had both moral and economic grounds, for the most part the institutes struggled to attract enrolments and remain 
focused on industrially aligned programmes of education. Australian settlement at this time was minimally industrialised and those who may have been eligible to attend were otherwise occupied during the day-working. They therefore had limited time or incentive to further develop their skills in the evenings. With inadequate enrolments, the mechanics institutes/art schools found they had to diversify their offerings to remain viable. ${ }^{2}$ Baragwanath (2000) described the change in orientation during the nineteenth century from the working classes to the middle classes. As the nineteenth century progressed and with low numbers of 'working men' enrolled, mechanics institutes became less oriented towards the working classes and more towards the middle classes, delivering courses that could be described as literary and popular amusements (Baragwanath 2000, 15). Nevertheless, despite the largely middle-class enthusiasm that greeted the establishment of the mechanics institutes and their libraries, the decline was inevitable, especially given the high costs and difficulty of raising funds to maintain library stocks; books were yet another manufactured item the colony largely imported from Britain. Without significant government investment, mechanics institutes were under financial duress from the outset. The story of the establishment and decline of the mechanics institute movement is remarkably similar across Australian cities and towns; then as now cultural, civic and educational ideals and investments were at the mercy of shifting regional economic fortunes and political agendas.

\section{Training to Support a New National Economy}

On 1 January 1901, Australia's colonies federated to form a single new nation. With the heyday of the mechanics institutes now past, schools of art and design emerged from the movement and took a more active role in working to develop local industry. Notably, it is in the contemporary manifestations of these earlier institutes of learning where many of our project research participants acquired the knowledge and skills that they now apply to their making practice and creative enterprise. Space does not allow us to do justice to the full national history of the development of this particular educational sector, nor was this a focus of the project, but because these legacies inform the kinds of education available to many of our participants, we will explore one particular state context.

South Australia, with its strong twentieth-century industrial focus on manufacturing, offers a valuable case study microcosm. South Australia was hit hard in the 1980s as a result of restructuring and the offshoring of 
manufacturing production to cheaper labour economies (as also was the nearby state of Victoria). The link between craft, industry and design has less history in Australia than elsewhere (notably the UK: Banks and Oakley 2016). However, for almost 50 years in the capital of South Australia, Adelaide, this link has been at the heart of the internationally regarded JamFactory, established in 1973 by the innovative state government of Premier Don Dunstan. The JamFactory in turn reflects a longer strong commitment in the state to applied arts education. As author, journalist, social historian and art critic, Peter Timms (2002) states, thanks largely to the pioneers Charles Hill and Harry Pelling Gill, 'South Australia led the other states in the development of arts and crafts education' and was first to master the promotion of classes in architecture; decorative design; metal, wood and leather work; as well as painting and sculpture (38-39). Adelaide was also home to the largest collection of Morris \& Co. items outside the UK, thanks to the keen patronage of the firm by some of the colony then state's richest families.

Neville Weston (1991), practising artist and art educator, provides deeper insight into the development of art and craft education in Australia. His doctoral thesis provides an interesting account of the origins and development of art school education in Australia through investigation of the relationship of British and Australian education systems and considers the impact of and resistance to innovation and change in visual arts education. He also discusses a case study from South Australia, looking at the establishment and transitions of the Adelaide School of Arts.

The Adelaide School of Arts and the South Australian Society of Arts were founded in 1851 by Charles Hill and it is from these that the current Royal South Australian School of Arts has evolved. Following Charles Hill's departure from the school and coinciding with the Industrial Revolution in Britain, H.P. Gill became principal of the School of Arts comprising Schools of Painting and Design (1882 and 1915). Gill advocated that the 'minor arts' should be considered the equal of painting and sculpture. He proposed that the basis for all art education, from primary to tertiary levels, should be Walter Smith's South Kensington System of drawing instruction, concerned primarily with artisan education and the production of artist/designers for industry (Weston 1991, 113-114). Both Gill and Hill, like many others across the colonies, were influenced by the British Arts and Crafts Movement. The associated arts and crafts societies, the 'working guilds' espoused by Arts and Crafts magazine, ${ }^{3}$ 
were of major importance to Australian craft, and indeed to the arts in general, until the 1939-1945 war (Timms 2002, 38).

With the decline in enrolments in many of the mechanics institutes, boundaries began to blur between training in what today we would call 'fine arts', and the materials-based making skills of the applied arts or craft applied in industrial or small-scale manufacturing sites, and training in what we now consider to be contemporary design practice. Peter Timms (2002) describes the latter as more akin to:

trades drawing. Art courses were basic training for mechanical or sanitary engineers, plumbers, metal workers, joiners, carpenters and masons. What may be called High Art occupies but a small space in the work to be done, and such of it as is done is undertaken primarily because of its use in the application to industrial art, and every Branch of Art is applicable to Industrial Art. Even china painting classes, introduced in some states as early as the mid-1890s, were supposed to have an industrial art basis, along the model of the English artwares studios but the rationale behind this was rather more tenuous. (38)

With the colonial population focusing on developing the sites and infrastructure to support the growing colony, the acquisition of objects of fine art relied on their importation rather than local production. Furthermore, as Timms (2002) observed:

there could be little justification for a school of fine arts and little chance such a school would secure private or public funding. Gill's course of pursuing applied arts that were likely to be useful for the improvement of manufacturers was, therefore, the sensible option. [ ... ] Not until the late 1930s did this bias towards the useful arts give way to greater emphasis on painting, printmaking and sculpture. (39)

This complex history continued to shape crafting and associated practices in Australia throughout the twentieth century. Design historian Michael Bogle (2002) observes that, despite 'Australia's failure to industrialise until the early decades of the 20th Century [it] continued to valorise craft skills and kept ceramics, woodworking and textile arts courses in the many technical college curricula after they had withered away elsewhere' (p. xv). These courses supported the training of apprentices in industries such as textile clothing, footwear and the furniture industry until the reduction or total elimination of tariffs and award restructuring 
that led to the loss of many family owned, small-scale manufacturing businesses from the 1980s onwards (Tanner 1999). Ultimately, this impacted on the number of courses delivered by trade schools and opportunities for apprenticeships in craft-based manufacturing.

\section{The Rise of The Universities}

Craft education in Australia had therefore been shaped by multiple influences, including initially imperial ones and then the economic and social projects of the newly independent colony. From the Second World War onwards a series of initiatives by national ('Commonwealth') governments first promoted vocational technical education in Australia and then, in the late 1980s, abruptly abolished it, transferring the focus to the university sector. Constitutionally, the Federation of Australia in 1901 gave the Commonwealth government no direct role in education; this was considered a state responsibility. Consequently, Commonwealth involvement in education in Australia was minimal until the 1940s, when technical education became a vital part of the war effort for the Second World War. The Commonwealth provided financial assistance to the states for the development of technical education through the Commonwealth Office of Education, created in 1945 under the auspices of the Department of PostWar Reconstruction. However, as Goozee (2001) observes, the Commonwealth's interest in technical education virtually died at the end of the war. Don Smart, professor of education at Murdoch University, reminds us that it was not until the 1950s that the Commonwealth displayed a top-down involvement in education through numerous committees of enquiry, starting with the Murray Report and the creation of the Universities Commission (cited in Goozee 2001, 8). Following the establishment by legislation of professional registration boards for occupations that once resided in the institutes, such as Engineers Australia and the Australian Institute of Architects, the criterion for professional registration was determined to be at degree level rather than the traditional technical education diplomas. Consequently, many of these courses moved (usually at the request of the relevant professional body) to the Commonwealthcontrolled university sector. Some would argue that status considerations rather than for any significant concern for educational rigour played an important part in these decisions (Goozee 2001, 9).

The college of advanced education (CAE) sector had been founded as

a Menzies government (1949-1966) federal response to the 
recommendations of the Martin Report for the Committee on the Future of Tertiary Education (1964). The CAEs were usually based on earlier technical colleges, teachers' colleges and other post-secondary vocational institutions. Although presented as 'separate but equal', their chief responsibility was to provide vocational courses at sub-degree (i.e. diploma) level. Until 1974, the sector comprised mainly technical, agricultural and specialist paramedical colleges. In that year, the state government-controlled teachers colleges became CAEs, with the result that teaching students now comprised half of all students in the higher education sector (Goozee 2001, 7).

However in a dramatic subsequent change, between 1989 and 1992, the Hawke-Keating government's minister, John Dawkins, implemented sweeping reforms of higher education in which the CAE sector ceased to exist, being subsumed instead into the university system. This coincided with significant restructuring of the Australian economy from the 1970s to the 1990s, including the privatisation of many government instrumentalities, the deregulation of the financial system, the unleashing of competition policy, award restructuring and a reduction or total elimination of tariffs (Tanner 1999, 20, 65, 66). These restructurings had important implications for the links between craft education and industry in Australia, as it ultimately led to the rapid decline of much of Australia's manufacture of consumer goods and the loss of many family owned, small-scale manufacturing businesses such as ceramics factories; textiles, clothing and footwear factories; and furniture factories. These changes to government economic policy resulted in the decline of apprenticeship employment and reduced the need for training in these artisanal manufacturing skills.

Writing in the wake of the Dawkins era, during which time the more independent or technically focused art schools were folded into the university system, Mike Press and Alison Cusworth (1997) offer a nuanced description of the craft of object making, describing the contestation between the academic focus of making courses within the university system as opposed to other sites of adult education, where making and creative enterprise skills are sought:

Craft contains its own thinking, its own knowledge, some of which is reducible to words, but most of which takes place through the physical act of making and is manifest in the crafted object. Craft knowledge is gained and passed on through the use of all the senses. It is possible to write an account of how to blow glass, but this does not constitute the knowledge of glass 
blowing. This knowledge is acquired, and developed further, by understanding the material's qualities at different temperatures and sensing how the fluid material is best manipulated: through sight and touch. (Press and Cusworth 1997, 15)

This transition point is where the history of the evolution of the craft and design education in Australia begins to be reflected in the experience of our research participants. The absorption into the university system of visual art, craft and design programmes from technical colleges catalysed a change in pedagogical focus for many design- and craft-based programmes. Many of our established makers commented on how fortunate they were to study during a period in which education was free and their time in the studio was virtually unlimited. In 1989, the Hawke Labor Government began gradually re-introducing fees for university study and since this time fees have steadily increased as has the average level of graduate's HECS (Higher Education Contribution Scheme) debt, meanwhile the income threshold that triggers the repaying of fees to the government has lowered. This change in policy is also noted by many of our emerging makers who similarly bemoaned the fact that as Commonwealth university funding shrank so too did studio time, so much so they felt ill-prepared in certain aspects of their making and enterprise skills to venture into professional creative work on graduating from their studies.

\section{The University EXPERIENCE}

These Australian changes of the 1980s are associated with a shift of focus in arts, craft and design education. Discussing a parallel transition in the British context, Banks and Oakley 2016 suggest that the earlier educational focus had been on the cultivation of an artistic or creative person as a particular 'type'. Similarly, Alan Barcan (1978), in his rather strident critique of the amalgamation of the CAEs into the university system under the Hawke-Keating government, considered that:

[Academisation] throughout the western world schools, colleges and universities have relaxed their previous emphasis on developing minds and character. Acquisition of knowledge, ability to interpret information, acquisition of vocational and other skills, and the production of a given type of character have fallen into disrepute. Instead, the achievement of formal qualifications through enrolment in a higher education institution has become more 
important. Certificates, degrees and diplomas are valued in themselves, rather than for the abilities and knowledge which they should symbolise. In any case, this ability and knowledge has become more and more theoretical rather than practical. (41)

Alongside the pedagogical shift from hands-on to more theoretical classroom modes, there was a tightening of university funding mechanisms and a consequent rationalisation in investment in staff levels and student contact hours. This pressure to wind back the availability of studio practice and the follow-on negative impacts on contemporary arts, craft and design graduate's practical skills was a recurrent theme throughout our research. Australian National University School of Art academics Nicol and Rubenis (2015) commented on 'the challenge of maintaining media-based programmes [i.e. materials-based] that require small classes, intensive one-on-one tutorials, extensive infrastructure and time, and specialist teaching and technical staff' and the financial handicap it placed on such intensive media-based training in comparison with 'other creative disciplines, especially those that are digitally based' (2). Their observations were certainly confirmed in our study. For example, as one of our research participants in the study commented:

To tell you the honest truth, [it's] left up to the individual to work out how to make; there's, now especially, I mean [since] I started they cut it [studio time] from 6 hours to 4 hours, now it's down to 3 hours. (Misha Dare, jeweller, emerging maker, April 2016)

Towse (2003), making a similar observation more than a decade previously, concluded that, at the level of tertiary education, the human capital investment is 'less efficient' for arts occupations. The restructuring of the higher education sector in the late 1980s included the absorption into the university system of many of visual art, craft and design programmes from art and craft schools, colleges of advanced education, independent institutions and vocational schools or technical colleges. This amalgamation has highlighted the tensions and value-laden differentiation between university education and education traditionally offered by technical colleges or TAFEs. The former involves what are considered higher cognitive skills, a more theoretical approach and a more straightforward pathway to employment, whereas the latter offers a more hands-on education with a focus on manual and technical skill. 
In the disciplines of applied arts or crafts, where learning is structured around doing, this diminution of time in the studio has had a significant impact on the calibre of making skills acquired by emerging graduates. Our participants who studied within both the university system and TAFE were able to provide insights into the different pedagogical approaches and institutional cultures and their personal experiences during their time studying:

The course at RMIT [the Royal Melbourne Institute of Technology, a joint university-TAFE that grew out of the amalgamation of more arts and trades-based precursor institutions] is very much a skill-based course and it's, in typical sort of TAFE fashion, you work through modules and you learn particular skills and then you had to produce something that shows that you've acquired those skills. And [it's] very basic in terms of things like learning how to make a hinge or how to make a clasp or the sort of [ ... ] skills that need to be there. The RMIT [course] is actually far more [for you if] you're a fine artist and the media you're using is not very often even gold and silver, it's all sorts of things. So that's become a-that's a much more, I suppose, creative and conceptual course. And the NMIT [Northern Melbourne Institute of TAFE] was [a] much more structured and skillbased course and I much preferred it. [ ... ] I got a lot of challenge out of RMIT in terms of being taken out of my comfort zone and being able to or being asked to explore materials that I otherwise maybe wouldn't have touched. However, it frustrated me that skill was not what was appreciated. (Alannah Sheridan, jeweller, emerging maker, March 2016)

The influence of this change in training and educational experience and skills acquisition is thus clearly apparent in our study when comparing experiences between the emerging and established makers who participated. The established makers commonly undertook their formal education during a time when there was greater government investment in education and the arts. In addition, during the formative stages of practice development, they were able to access a more generously subsidised range of arts funding programmes than are on offer today.

\section{Twenty-First-Century Craft and Design Education in Australia}

Writing in 1991, writer and artist Don Ellis suggested that, once amalgamated, craft and design education had to be 'intellectualised' in some way in order to meet the tradition of university education. Furthermore, 
he argued that art school policies were leading to too many programmes, which generated an oversupply of artists facing inadequate employment prospects. Many critics consider that all of these consequences are today visible in Australian university education in art, craft and design. A subsequent development is that universities have been pressured by the government to produce greater efficiencies and employment outcomes for the public monies invested and consequently have been forced to rationalise the extent of their disciplinary offerings and modes of delivery. Studio-based disciplines that require hands-on time to acquire skills, are physically resource intensive and do not have direct employment outcomes have been among the first to face rationalisation andin many instances-demise. All this is taking place within a larger political, economic, industrial and cultural context in which science, technology, engineering and math [STEM] disciplines are valorised as the saviours of our economic futures, rendering low-tech craft production and education outmoded and redundant (Press and Cusworth 1997, 13).

In 2016, Australia's then federal education minister Simon Birmingham asserted that training in the creative arts is a 'lifestyle' choice and cannot lead to a satisfactory career or any economic outcome (Caust 2016). This dismissive attitude could be seen simply as a manifestation of the minister's and government's generally conservative principles. However, it is also strangely outdated in its implication that to be legitimately employed in work they should be employed by someone other than themselves. This lack of recognition of the validity of relevant self-employment is illustrated in reports such as the Beyond Graduation Survey which found that creative arts graduates are the least likely to be employed in an occupation linked to their degree three years after completing their qualification (Graduate Careers Australia 2009). All this has most recently prompted the question: When training people in these practice-based areas, what skills development is needed to enable contemporary craftspeople and designer makers to run a creative enterprise in the digital age? In the next section, we address this issue, drawing on our interviews with makers and with representatives from industry organisations. 


\section{Getting Down to Business: Professional Skills in Practice-Based Education}

You have to be good at lots of things, to wear lots of hats really well, to be a bit of an all-rounder. (Kath Inglis, jeweller, emerging maker, October 2015)

During the course of our research project, a growing body of discourse converged from a number of policy, industry and academic perspectives on the need for all students including those enrolled in fine arts programmes to develop not only disciplinary-specific skills and knowledge through their undergraduate degrees but also transferable skills (Fletcher 2016, 117; Haukka 2011). Commentators argue that this preparation is required to place students in good stead to navigate an increasingly ambiguous, flexible and unequal employment landscape (Banks and Oakley 2016; Bridgstock 2005, 2011; Brook 2016a, b; McRobbie 2004, 2016; Oakley and O'Brien 2016; Throsby and Petetskaya 2017;Throsby and Zednik 2010). The skills are additionally important in current contexts where there are more creative graduates than there are sustainable employment options for them to take up and where entrepreneurial discourses are normalised and 'the self-employment ethos [is] now a necessity for survival' (McRobbie 2016, 4).

The promotional literature of most Australian universities is notable for language that appears to address these challenges. Students are offered opportunities for engaging with industry and future employers through Work Integrated Learning (WIL) opportunities to develop or enhance their transferable skills. In addition, many universities offer support for current or recently graduated students to pursue the development of an enterprise through start-up initiatives or hubs. However, as is the case with the authors' own institution (the University of South Australia), the recipients of funding and support from the start-up hubs are mainly from the STEM disciplines. As Bridgstock and Cunningham observe in their paper on creative labour and graduate outcomes:

There is no single mandated curriculum for higher education. There are also few professional accreditation requirements in the creative industries. This means that institutions are free to determine their own graduate capabilities and program learning outcomes. Australian Qualifications Framework stipulates that Bachelors degrees in Australia will 'have advanced knowledge and skills for professional or highly skilled work and/or further learning', 
but do not stipulate the actual knowledge and skills required (Australian Qualifications Framework Council 2013). [ ... ] these frameworks have been criticised for insufficiently addressing 'twenty-first century' capabilities such as entrepreneurship and career self-management, lifelong learning and metacognition. $(2016,13)$

The importance of embedding 'enterprise education' in their undergraduate programmes has been recognised by cultural and creative industry researchers, economic anthropologists, educational researchers, policymakers and universities themselves. It is therefore surprising that there appears to have been minimal pedagogical response to embracing and embedding entrepreneurial and enterprise development skills within the arts curriculum throughout the years of the degree.

For this reason, many of our interviewees felt that they were ill-prepared to establish a creative enterprise but were less sure regarding whether the problem was a failure of provision or them having being naive or inattentive students (see also O'Brien and Kerrigan 2020). Here, Emma Young, an emerging glass artist, reflects on her understanding of what establishing a creative practice might entail following graduation:

I definitely think that [my degree] was not business-focused at all. Not in the sort of way that I went through anyway. There was so much focus on just building a concept because how many skills can you learn in, like, two years blowing glass? It takes years and years to learn how to make anything properly. [ ... ] So we're kind of just pushed just to follow the assessment and just to get through uni really, and then maybe if you do honours or if you do any sort of postgrad then maybe there's more of a focus on the business side of things. But I think definitely [ ... ] we were more, I don't know, encouraged to be a visual artist rather than business people, and I knew that I didn't want to be [just] a visual artist. (Emma Young, glass artist, emerging maker, March 2016)

\section{Others had a more positive experience:}

There was a bit of stuff in the final year which was really helpful. [ ... ] And there was a couple of units, like a professional practice unit, which was very helpful just in terms of understanding figures, numbers, what's required to make a business work, in terms of if you want to stay in business and you want to employ this many people or whatever it is: "This is the hourly rate you have to charge to cover these costs." Very basic stuff, but stuff that you 
really need to know otherwise it's not going to work. So that was quite helpful. (Scott van Tuil, furniture maker and designer, emerging maker, February 2016)

Although most of the emerging makers could recall having had people come in to speak to them during their university study about the business side of creative practice, overwhelmingly, these messages were experienced as 'not sticking' or not valuable, or they simply may not have realised the significance of the information being conveyed at the time:

I just wasn't in tune with what was being said at uni because you don't really understand the context all that well, or actually it wasn't taught very well. It maybe is a little of both. (Scott van Tuil, furniture maker and designer, emerging maker, February 2017)

Some of the reasons for this (as the participants themselves acknowledged) have to do with youthful arrogance or a lack of focus on the world after completing their degree, but more often there was a sense that the information was too esoteric or not relevant enough at the time to be of any value to them.

The kind of business information and knowledge they found useful, no matter where it was sourced from, was about bigger picture and more strategic considerations. Therefore what they did find useful was when successful makers came in and talked about their (macro) business model, that is, how they had gotten where they were through trial and error, by balancing jobs; deciding on brand identities, products and locations; taking on creative or non-creative work; choosing to focus on product lines or gallery work; and/or focusing on grants or adopting a more business growth-oriented model from the get-go. As emerging maker, Cara Pearson, recalled:

They leave that professional practice side of that really late in the degree. [I'm referring here to] professional practice, which I guess is the only subject that you have in the bachelor's degree that gears you towards doing anything outside of what you've learnt or outside of your little bubble of university $[\ldots]$ But you kind of come out of it and it doesn't give you that much of a support for where you're going to go. They try, I think there's the delineation between the students who really do want to go on and become a successful independent artist, and the students that go on to do teaching or go on to do a further degree and are not necessarily interested 
in it, because a lot of them don't see the value in learning how to write grants and learning how to do all of that. But a person like me who wants to [ ... ] learn, wants to continue to build upon my skill, that's something I consider that's essential in terms of developing a business, I mean there's next to no support in that sense that I probably tried to do a lot of what I have done on my own. [ ... ] We had a lot of people come in and talk about how they, like it was pretty much, like professional practice is pretty much just about grants writing, and you don't get much else out of that to be honest. We had people come and talk about their success stories but never about running a business, I think that's something that's kind of completely overlooked in that sense. I'm trying to remember what the syllabus was, but it was mostly around grants and writing, like, you know like [ ... ] essays and things like that. [ ... ] I think for me it's something that needs to be addressed earlier in the degree. (Cara Pearson, studio glass, emerging maker March 2016)

The craftspeople and designer makers we spoke with were more concerned with balancing creative and non-creative work to make ends meet, how to strategically develop and communicate about their creative enterprise, finding the right outlets and galleries for their work and negotiating contracts and when, where and how to apply for grants and skills development residencies. Although many would begin this information-gathering journey with a Google search, a key factor in the development and continuation of the creative practice and enterprise of many of the makers we interviewed was building upon this earlier visiting practitioner experience in the classroom by having a mentor, either as part of a formalised program or through personal networks.

Others we interviewed found aspects of the professional practice subjects they had undertaken useful, but could not see how, at least if done at the necessary level of detail, they might fit usefully into an already crowded curriculum:

Well I do know in the undergraduate course that I did we had a class that was called professional practice, which I always felt like it was such a wasted opportunity because the premise of it was to teach you a lot of those things but it was just so lightly skated over. So we had one class that was tax and an accountant came in and talked to us; we had one class that was grant writing. [ ... ] That was the only experience I had with that and so I think it would be great for it to be in undergraduate, but I don't know where the time and the space within a degree [could be found]. (Clare Poppi, jewellery, established maker, September 2016) 
Given this perception of lack of space within the studio-based making curriculum, just what skills did contemporary craftspeople and designer makers consider they needed, either looking forward to their future career or looking back over an established career? Arguably, the answer that captures the essence of our findings came from emerging maker Naomi Stanley, when asked what skills she considered necessary run a successful enterprise:

[You need] heaps. You just need to be everything and it's a bloody big ask for one person. Like you can't do it all at once. You need to have-you need to be marketing savvy; you need to identify your market and stuff. (Naomi Stanley, shoe maker, emerging maker, October 2015)

A fellow emerging maker's response reflects what many of our interviewees considered to be the most challenging aspect when first setting out to sell their work, after or even towards the end of their degree:

The pricing, the marketing, the understanding of "how to", yeah it's really just the pricing/market thing that as a designer you probably need to have. But again, when we are creative we, sometimes, you just want to create; you don't think about ... it's not that the uni doesn't [mention it ... ] but they don't teach you the business side of things. Right? Yeah, they touched very little on it so it's quite hard to manage, yeah. [Admittedly] in uni you probably don't know what you want yet. So when you can't decipher that you can't find a focus, when we've been given so much information it's not [ ... ] ideal I feel. It might confuse you even more. (Textiles, emerging maker, April 2016)

We heard many interviewees say they had faced a steep learning curve when they realised that, if they were going to continue their making journey and set up a viable creative practice, they would need to be selfemployed. Interestingly, few were particularly concerned about the minutiae of doing their accounts:

So it's really funny, when I first started, when I first finished uni I really wanted business training. You don't get any of that from uni and I sort of undertook to take, I didn't do any formal TAFE or other courses like that, but I did a lot of one-day workshops in how to do bits and pieces, and from that I pretty much learnt that I don't have an excellent head for business and I should outsource a lot of those things. So yeah. So taxation and things like that it's just whoosh. So I just have an accountant that I pay to do that. (Clare Poppi, jewellery, established maker, September 2016) 
Although most of our emerging makers (especially the so-called digital natives) felt relatively comfortable with digital communication tools (see Chap. 8 for further discussion of this), many faced challenges - not only in timing and tone of communication about themselves and their work but also in getting their online stores working and maintaining them. This was more challenging and time-consuming than they had at first thought. Emerging maker, Natalie Lane, was particularly resourceful in addressing the challenge:

Q: 'And in terms of moving forward, what kind of skills development, if any, do you think you need or would you like to be able to get?'

A: 'One is definitely the online, with the website. So I'm doing a lot of the tasks myself, there's not a lot that I've outsourced-photography, I did get a photographer early, because I thought that was important to the website. I [also] had help with my website. [I asked a friend who is a professional photographer] and the first shoot was an exchange - an exchange of skills and products [ ... ] which was a nice way to start. [So also] things like how to make your website run faster. So there's that side of things, or customising things, say even something as simple as if when someone makes a purchase if they could choose to also buy a greeting card and have custom text inside. And just actually making that all be able to happen easily on the website is outside of my skills. So I need to include a [web] developer. [ ... ] I think part of it is not [acquiring some skills yourself, but rather] reaching out to people who have those skills, who are professionals. Not to say that there aren't skills I need, there's plenty, but I suppose the first thing I was thinking of was being able to access people who have skills. Whereas [at] these early stages you're just figuring out how to do everything.' (Corner Block Studio, picture frames, emerging maker, November 2015)

\section{Drawing on Previously Acquired Transferable Skills}

Not all makers come to their creative business direct from university; even those that do tend to have part-time employment to support them through their study. As a result, when seeking to refine their self-employment or small business skills, many looked to other retail or business experience rather than formal education. We asked the career changers among our 
interviewees (those who began their working lives in other industries before establishing a craft or design-based enterprise) to reflect on the transferable skills they brought from their previous work:

I did the science degree and then after that I did a postgrad in business and that really helped set me up, and I think that's one thing that I can see [makes] a difference in my professional realm is seeing that artists versus designers do have a different set of skills. I would class myself as a designer because I'm too practical sometimes, and those skills were very useful in the business entrepreneurial side of where I took my creativity. (Kate Evans, textiles, established maker, October 2017)

One of our emerging makers had a background running a business as an electrician, which he said made him more aware of the pitfalls to avoid.

I've had an electrical business before [and] a lot of it was just the same skill set in a different field, it's just all about making sure you're not overspending, keeping account of everything, making sure you know exactly what your hours are and things like that. [...] So when you quote you now quote properly because you're not trying to undercut yourself and end up working for ten dollars an hour just so you can get the job, it sort of defeats the purpose of it. (Furniture, emerging maker, February 2016)

Many of our makers found they drew a lot from their experience of working in retail, whether in the arts/design sector or other nonrelated retail:

It was actually a good experience to have because it gave me skills in order to sell my own work, which was harder, and then it also gave me a lot of small business skills because I mostly worked for smaller companies. So, I actually learned a lot of skills in those years I was doing retail, particularly when I worked in the United Kingdom. I worked for a small company and they just threw everything at me-lots of different aspects of the business. So, it gave me a really broad idea of actually how to run things. (Corinne Snare, silversmith, established maker, February 2017)

When asked to reflect on the skills other than the making/creative skills that she drew on in her practice, an Adelaide-based ceramic artist identified her experience working in the hospitality sector as enabling her to communicate with clients more effectively: 
All that gives you a sense of confidence in terms of answering enquiries or how you approach people that you work with and I think that's always helpful. And also in terms of response times and having a bit of work ethic behind that, [it] certainly helps because if I have someone I haven't [got] back to, I certainly feel it because I'm used to feeling that in other job situations. So [ ... I I think it makes you quite professional in terms of how you interact with prospective clients or stockists or galleries and I think it also helps you in terms of pushing yourself to make sure that you get yourself out there and understanding a little bit about the work behind the scenes in terms of running a business and, and how you, how you get on with that. (Ulrica Trulsson, ceramic artist, established maker, August 2015)

Established maker Hayden Youlley found his work experience in furniture retail invaluable on many fronts. This included observing customer buying behaviour, identifying market trends and opportunities and the all-important communication skills:

While I was there, the managing director and the designer of all the furniture $[\ldots]$ really taught me a lot about designing for sales. So what I learnt there was really invaluable. So I learnt things like how to approach clients, how to talk to clients, who my target market was, how to position myself in the market. I got a really good understanding of what was available, in the sort of high-end, handmade designer ceramics, because that was part of what we sold. So I got a really good understanding of what was available, where the gaps were in the market, and I started to develop also in my aesthetic. So seeing what was on the shelf, and what people interacted with, really did start leading me into, "Okay yeah, I really like that as well, and it also sells," that's extra incentive to develop that part of my aesthetic a little bit further. So it was a really good training, like really good practical endgame training. [ ... ] I also learnt the [other] side: as a maker, how do you approach someone like [my former managing director] or a shop like Planet to get them to sell your work? [ ... ] I saw people do really well at that, and I saw people do really bad at that. So I got a really good sense, [that] you don't just walk in off the street and be like, "Here's my work," because nobody wants to deal with you. You learn things like that. And a simple email is actually really effective, and the images that you present in that email are also extremely important, because people are going to take a first look and get a really quick impression of you, and that's really important to solidify your product in their minds, because they're making decisions very quickly. [ ... ] So I knew coming out of [my degree and] approaching my 
own practice that photography and really good style photography was going to be very important to my success. (Hayden Youlley, design, established maker, August 2016)

'Getting your work out there' and visible, which is important not just in the physical marketplace but also in the online marketplace, also unfortunately increases the risk of copyright infringements by others inspired by your work. Such copying was not unique to furniture makers, but it had impacted proportionately more of them within our research cohort. When asked about their level of concern in protecting their intellectual property, many of our interviewees were remarkably pragmatic about beating copycats, preferring to stay ahead of the pack rather than enter into emotionally and financially costly litigation.

\section{Creating and Communicating Personal Narratives}

A particular communicative skill that was relevant for our interviewees was that of presenting themselves through a personal account or life narrative. Throughout history, compelling individualised narratives have helped to sell things, especially when asking people to part with discretionary income on things that are not essential to daily life. Still today, gaining a prospective client's attention is critical; image is everything, as is cultivating your own brand, even if that 'brand' is you. In the Global North, where it seems almost everyone connects to the crowded internet marketplace for business and pleasure, being an all-rounder in this area of enterprise development is particularly pertinent. While many of our interviewees acknowledged that they were shy and really just wanted to focus on making, they found self-promotion almost obligatory and writing a compelling personal narrative for their online sites particularly challenging. As Morgan and Nelligan (2015) observe:

The myths of meritocracy are shattered as creative aspirants come to realize that they are often judged in ways that have nothing to do with their skills, and that in order to succeed they will have to change, for example the way they speak, dress and present themselves. (70)

Despite the increase in avenues for online promotion of their work and online selling platforms, our makers clearly articulated the benefits of faceto-face selling environments. Such environments provide the opportunity 
for potential buyers to talk directly to the person who made the work, to acquire a deeper understanding of its production and the person who made it and thus to differentiate the object from others competing for the buyer's attention and dollars. But being able to market and communicate effectively across both online and face-to-face contexts was a challenge for many of our interviewees. When asked if they could put their finger on anything they would have like to have learnt in their course, many (often self-confessed introverts) reflected on the need to develop their communication and sales skills, as well as public speaking generally:

Public-speaking abilities. I'm lucky, the one thing I've had to learn going to a few different trade shows is people want the story behind the piece and if you can't engage the people they're not interested. And some people are very small-mannered people, [they] just want to look at things and don't want to get spoken to. But a lot of people want a story and I thought I was getting into this industry because I could just whittle away and do whatever I want, [ ... ] but it's really not that. [For example,] I've got to do a floor talk tomorrow night. (Furniture, emerging maker, February 2016)

Clearly, the skills to run a successful making enterprise are garnered from both explicit knowledge exchange and skills development through formal education as well as tacit knowledge and skills development through work and life experience, within as well as outside of the creative industries.

\section{Crafting a Career Progression: Filling THE SkILls Gaps}

The previous sections have indicated some of the skills areas that are important for both emerging and established makers. In this section, we review some of sources of support that our interviewees said that they had found helpful.

\section{New Enterprise Incentive Scheme}

When we asked our interviewees directly about the support they considered necessary to develop a successful making enterprise, what was overwhelmingly evident was the importance of the ability to access business skills when they need them. As we have seen, generally this was not during their undergraduate training and often did not even coincide with formal 
training or professional development events run by industry groups and business support organisations. Our participants acknowledged the importance of soft skills to succeed in this space, but they sought them in multiple ways, largely as part of a continuing process of professional development. In addition to the important role mentors played in makers' career development, other key sites of collegial sharing of information and knowledge included the New Enterprise Incentive Scheme (NEIS), shared studios, co-working spaces and artist-run initiatives. Our interviewees shared insights into their experiences and the impact these initiatives had on the development of their creative enterprise.

With the apparent lack of exposure to information about enterprise development and business management, or an inability to contextualise learning something unless actually applying it in daily life, it is hardly surprising that few of the emerging makers we interviewed had a written a formal business plan, or had anything more than a hand-to-mouth approach to managing the financial side of their business. A standout finding arising from the question 'Have you ever put together a formal business plan?' was the number of makers who, to make up for the lack of business skills development during their time in higher education, acquired the information through the New Enterprise Incentive Scheme (NEIS). The Commonwealth government-funded NEIS provides registered job seekers (i.e. those eligible to receive unemployment social security payments) with:

- accredited small business training and business mentoring for up to 52 weeks;

- income support for up to 39 weeks (NEIS allowance) and NEIS rental assistance for up to 26 weeks (if eligible); and

- personalised mentoring and support from a NEIS provider in the first year of the new business to help put their business idea into practice. (Australian Government n.d.)

Of our interviewees who had written a business plan, many had done so while undertaking the NEIS and all acknowledged its positive impact on the development of their enterprise:

I did a NEIS course and that was fantastic because they do this thing where they make you figure out what your competitive advantage is, which took me weeks and a lot of tears and going 'no, I'm no different to any furniture 
designer, how am I ever going to make a successful business?' But what I figured out from that was there was lots of wooden cabinet makers and people who did benches and tables and none of that has changed, but there weren't many people doing upholstery. So that's where I went, I'm focusing on the upholstery side of things and going from there and I still keep that upholstery focus and it's interesting when I do collaborate with architects [which I do] all the time now, the fact that I do the upholstery side of it they really appreciate that because they can knock up joinery designs and stuff no problem, but they all feel a bit lost on that upholstery side of that because it is a bit specialist. So it was a good choice 15 years ago. (Julie Pieda, Koush Design, established maker, August 2015)

I did a course run by the Australian Government. It was called the NEIS Scheme. [ ... ] And that was amazing I have to tell you. That actually set me up. That started me to think properly about every step and this is how they showed me that you have to choose one day for your administration and that's normal. You have to have a day like that to deal with all the issues. So now I don't have to complain "Oh I hate paperwork and everything," I just do it in between and I just call it my administration time. But NEIS helped me to plan and to get all the ideas together. (Agnieszka Berger, ceramics, established maker, February 2016)

But, as mentioned, to be eligible for NEIS training, the applicant must be at the time registered for Newstart Allowance (an income support payment while unemployed and looking for work). This rendered most of the people we spoke to ineligible, despite the gains that such a focused and structured program can provide.

\section{Shared Spaces}

Although it provides a solid foundation, it takes more than writing a business plan to run a successful creative enterprise. To implement the plan, it is necessary to have skills that go beyond the ability to make the work to be sold. Ironically, those best able to survive in this space are not necessarily the best makers. Whether aiming for the high-end gallery or the Etsy 'high street', all makers need networks, and building networks means building relationships. A number of our interviewees were able to enhance their creative enterprise skills through the tacit knowledge exchange that comes with being a member of a shared studio space. For established maker Hayden Youlley, this experience was invaluable: 
When I graduated, I was in the position of working part-time in the design industry, sort of more in sales, and I lost that job due to downsizing and was put in the awkward position of do I try and find another job in the industry that I'm going to hate, or do I actually try and live out somewhat my dream job, which would be to make my own ceramics and design my own ceramics? Someone at that stage told me about the New Enterprise Initiative Scheme run by the government and I did some research and found it that it was perfect for someone like myself, who was looking to start a new business, and jumped at that chance. [I] put myself through the course, did really well, got my business plan in order, for my ceramic business, and when I finished that, I was lucky [ ... ] I was able to jump in as a resident at a ceramics studio on main campus at UNSW [University of New South Wales] and just started my business there under the kind of guidance of a few ceramicists who were already working there and [had] already established practices and established businesses. And they really sort of helped me grow and find my feet and really pointed me in the direction of what I needed to do to make it work, and to sell work and how to approach shops and how to approach stockists and get wholesale orders and what to do at a market stall and how that all plays out. So they were really, really helpful. (Hayden Youlley, ceramics, established maker, August 2016)

Similarly, Clare Poppi finds working in a collective studio space does more than provide her with the economic benefits of communal working; more importantly, sharing the space with others offers opportunities to share feedback about each other's work-something more challenging to gain if working solo:

When we started over there it was four of us that had gone through uni together and so since two of those people have left and gone on to do other things and then two new people have come [ ... ] And it's just really lovely, it's just a great community and everyone has different feedback but because we all have other jobs, our other things that we're doing [so] we're not all in here at the same time together so you get that time to yourself to actually work. And then sometimes you'll go "Oh, somebody else is here, this is nice we'll have a chat.” (Clare Poppi, jeweller, established maker, September 2016)

Established maker Vicki Mason found her time at Object Studios in Sydney invaluable in establishing her practice:

I think I was at Objects Studios for two years when Brian Parkes was running them and it was a professional development practice for young starter- 
outerers and they had Object Studios in Pyrmont. Oh my goodness that was invaluable, the people that came through those studio doors. They had a manager, there were about six or eight of us in there at a time, they had a visiting artists' residence, it was amazing. But that's where I really, they geared you up with your marketing, postcards were printed, you choose fonts for your business card, you talked, looked at the whole package, curators came through the doors, we were given opportunities to exhibit. That's when I got the mentorship to go to Gray Street [Studio in Adelaide]. That, that was invaluable and I think it's probably sorely missed, I've never seen anything quite like it again really. (Vicki Mason, established maker, jeweller, April 2106)

\section{Asking for Advice and Support}

Aside from any particular course or mentoring model that had been formative in the development of their business skills and practice, our interviewees had found it pivotal to be willing to ask for advice and support:

A combination of mentoring process and winging it, and also having friends who have done business stuff and just being willing to ask, I suppose maybe being willing to ask and being able to say you can't do something, can you give me advice-just asking for advice from multiple parties and figuring out somewhere in between is something I do a bit. And I suppose I learnt some generic skills as well through like activism, I was fairly heavily involved in it sort of when I was younger in particular, and it's one of those things that actually does train people up quite a bit, especially in communications. And it's a bit-sometimes having a conversation with someone about a product is a bit easier than having a conversation with someone about a heavy political issue, so it's interesting having like gone from one to the other and just going, okay yeah I feel uncomfortable, but you kind of just have to do it anyway, and you're not really, it's not really the biggest imposition to talk to someone, if someone doesn't want to talk to you they'll just say so. Saying that, everyone finds that stuff difficult I think, $\mathrm{mm}$ yeah, and so do I. (Duncan Meerding, furniture, established maker, February 2016)

\section{Personal Qualities}

What was clear from our interviewees is that, whether or not they felt their education prepared them for stepping up to the challenges of running a sustainable making enterprise, there were many things they were unlikely to learn in a formal classroom or studio setting. It was important to 
practice and develop crafty ways of doing things. Furniture maker and designer Liam Mugavin cited financial adversity and the challenge of making money from a creative enterprise as spurring him on:

A: 'You have to be persistent and willing to just live very basically, as you get started, because you won't make money for a while.'

Q: 'Has it been tough? While your friends have got jobs and buying cocktails, and you're thinking of staying home and have a beer?'

A: 'Well not really, because I'm naturally good at doing that. Yeah, I saved up a bit of money in Japan, as well, so I do have money to fall back on. I feel that that challenge actually fuels you to try to succeed and push your business further, because it means that making money isn't central and it pushes you to succeed. Whereas I feel that if I had a more stable income, I wouldn't push my practice so hard, if that makes sense.' (Liam Mugavin, furniture maker and designer, September 2015)

Established maker Anna Anago found that her 'relentless determination' enabled her to overcome the inevitable problems faced in establishing and running a creative microenterprise.

And not giving up when you get the first problem that comes about because what I'm finding is, you're just a problem solver in business, that's all you become, at the end of the day you've got little problems and big problems that pop up. And I'm one of those people that actually quite like getting the problem going, how am I going to fix it and coming up with crafty ways of fixing it. (Anna Anago, One Happy Leaf, established maker, November 2016)

Overall, we found that irrespective of where and how our makers gained the knowledge, skills and support to develop their creative enterprise, there were just as many personal qualities that they felt they needed to draw upon or develop.

\section{Notes}

1. For further discussion of the pathways chosen by aspiring creatives as they seek to enter the creative workforce, see Taylor and Luckman (2020).

2. See Banks and Oakley (2016) for a discussion of how art schools in Britain also emerged out of the nineteenth-century mechanics institute movement. 
In Australia, the emergence of the trades-oriented TAFE sector effectively served to again divide university taught arts/crafts from trade skills, leading to Australia not having quite the same kind of history of accessibility to the working-class art schools as was the case in the UK.

3. Arts and Crafts was a magazine briefly published in Australia in the 1890s.

\section{REFERENCES}

Australia. Committee on Australian Universities. (1957). Report of the committee on Australian universities (Chair: K. A. H. Murray). Canberra: Government Printer. Retrieved January 31, 2020, from http://hdl.voced.edu.au/10707/228224.

Australian Government. (n.d.). Small business training for individuals not in employment, education or training. Retrieved January 31, 2020, from https:// www.business.gov.au/Grants-and-Programs/New-Business-Assistancewith-NEIS.

Banks, M., \& Oakley, K. (2016). The dance goes on forever?: Art schools, class and UK higher education. International Journal of Cultural Policy, 22(1), 41-57.

Baragwanath, P. (2000). If the walls could speak: A social history of the Mechanics Institutes of Victoria. Windsor, VIC: Mechanics Institute Incorporated.

Baragwanath, P. (2011). Mechanics Institutes role in Australia's history. GuardianThe Worker's Weekly, No. 1526. Retrieved January 2, 2020, from https://www. cpa.org.au/guardian/2011/1526/12-mechanics-institutes.html.

Barcan, A. (1978). Exciting times for C.A.E.'s. The Australian Quarterly, $50(1), 37-50$.

Beddoe, J. (2003). Mechanics institutes and schools of arts in Australia. Australasian Public Libraries and Information Services, 16(3), 123-130.

Bogle, M. (2002). Introduction. In M. Bogle (Ed.), Designing Australia: Readings in the history of design (pp. xiv-xvii). Annandale, NSW: Pluto Press.

Bridgstock, R. (2005). Australian artists, starving and well-nourished: What can we learn from the prototypical protean career? Australian Journal of Career Development, 14, 40-48.

Bridgstock, R. (2011). Skills for creative industries graduate success. Education + Training, 53(1), 9-26.

Bridgstock, R., \& Cunningham, S. (2016). Creative labour and graduate outcomes: Implications for higher education and cultural policy. International Journal of Cultural Policy, 22(1), 10-26.

Brook, S. (2016a). The exemplary economy: A Hunterian reading of the creative industries as educative project. International Journal of Cultural Policy, $22,27-40$. 
Brook, S. (2016b). The creative turn in Australian higher education. In R. Comunian \& A. Gilmore (Eds.), Higher Education and the Creative Economy (pp. 242-260). London: Routledge.

Butlin, N. G. (2013). Investment in Australian economic development, 1861-1900. Cambridge: Cambridge University Press.

Caust, J. (2016, October 19). Arts training is an essential part of an innovative nation. The Conversation. Retrieved January 31, 2020, from https://theconversation.com/arts-training-is-an-essential-part-of-an-innovative-nation67303.

Committee on the Future of Tertiary Education in Australia, Martin, L. H. and Australian Universities Commission. (1964). Tertiary education in Australia: Report(Chair: L. H. Martin). Canberra, ACT: Government Printer.

Dolan, J. (2010, October 18). A history of mechanics institute libraries (blog. Retrieved January 1, 2020, from http://mechanicsinstitutes.blogspot.com/.

Ellis, D. W. (1991). A discourse analysis of curriculum documents taken from the internet on jewellery making in the academy. PhD thesis.

Fletcher, K. (2016). Craft of use. London and New York: Routledge.

Goozee, G. (2001). The development of TAFE in Australia (3rd ed.). Leabrook, SA: National Centre for Vocational Education Research.

Graduate Careers Australia. (2009). University and beyond: Snapshot report. Melbourne: Graduate Careers Australia.

Haukka, S. (2011). Education-to-work transitions of aspiring creatives. Cultural Trends, 20(1), 41-64.

Martin Report see Committee on the Future of Tertiary Education in Australia.

McRobbie, A. (2004). Making a living in London's small-scale creative sector. In D. Power \& A. J. Scott (Eds.), Cultural industries and the production of culture (pp. 130-143). London and New York: Routledge.

McRobbie, A. (2016). Be creative: Making a living in the new culture industries. Cambridge and Malden: Polity.

Morgan, G., \& Nelligan, P. (2015). Labile labour - gender, flexibility and creative work. In B. Conor, R. Gill, \& S. Taylor (Eds.), Gender and creative labour (pp. 66-83). Chichester: John Wiley \& Sons.

Murray, K. A. H. (n.d.). see Australia. Committee on Australian Universities.

Nicol, R., \& Rubenis, N. (2015). Crafting connected knowledge: Collaborative and problem-based pedagogy for the studio craft and design school. Paper presented at the ACUADS Conference 2015. Adelaide: Australian Council of University Art and Design Schools.

Oakley, K., \& O’Brien, D. (2016). Learning to labour unequally: Understanding the relationship between cultural production, cultural consumption and inequality. Social Identities, 22(5), 471-486.

O'Brien, A., \& Kerrigan, P. (2020). New entrants' narrations of their aspirations and experiences of media production work. In S. Taylor \& S. Luckman (Eds.), Pathways into Creative Working Lives. Cham: Palgrave Macmillan. 
Prahran Mechanics Institute. (n.d.). What is a mechanics institute? Retrieved January 31, 2020, from https://www.pmi.net.au/home/mihistory/.

Press, M., \& Cusworth, A. (1997). A new vision in the making: exploring the value of craft education in the information age. Design Journal, 1(Suppl. 1), 12-29.

Tanner, L. (1999). Open Australia. Annandale, NSW: Pluto Press.

Taylor, S., \& Luckman, S. (2020a). Creative aspiration and the betrayal of promise? The experience of new creative workers. In S. Taylor \& S. Luckman (Eds.), Pathways into creative working lives. Cham: Palgrave Macmillan.

Throsby, C., \& Petetskaya, K. (2017). Making art work: An economic study of professional artists in Australia. Strawberry Hills: Australia Council for the Arts.

Throsby, D., \& Zednik, A. (2010). Do you really expect to get paid? An economic study of professional artists in Australia. Sydney: Australia Council.

Timms, P. (2002). Art education in the schools and technical colleges. In M. Bogle (Ed.), Designing Australia: Readings in the history of design Annandale (pp. 38-42). NSW: Pluto Press.

Towse, R. (Ed.). (2003). Cultural industries: A handbook of cultural economics. Cheltenham: Edward Elgar.

Tuffin, R. (2013). Australia's industrious convicts: A reappraisal of archaeological approaches to convict labour. Australian Archaeology, 76(1), 1-12.

Ward, R. (2002). Ceramics report, in Casey \& Lowe Pty Ltd (2002). Archaeological investigation, Conservatorium Site, Macquarie Street, Sydney, unpublished report for NSW Department of Public Works \& Services, Vol. 4, Chapter 21.3.

Weston, N. (1991). The professional training of artists in Australia, 1861-1963, with special reference to the South Australian model. PhD thesis, Department of Education, University of Adelaide. 
Open Access This chapter is licensed under the terms of the Creative Commons Attribution 4.0 International License (http://creativecommons.org/licenses/ by $/ 4.0 /$ ), which permits use, sharing, adaptation, distribution and reproduction in any medium or format, as long as you give appropriate credit to the original author(s) and the source, provide a link to the Creative Commons licence and indicate if changes were made.

The images or other third party material in this chapter are included in the chapter's Creative Commons licence, unless indicated otherwise in a credit line to the material. If material is not included in the chapter's Creative Commons licence and your intended use is not permitted by statutory regulation or exceeds the permitted use, you will need to obtain permission directly from the copyright holder.

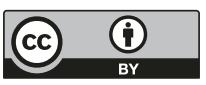

